\title{
Role of Grab on the social life changes of Bengkulu City
}

\author{
Afrima Widanti ${ }^{1}$, Dewi Rahmayanti ${ }^{2}$ \\ 1,2Faculty of Economics and Business, Universitas Bengkulu, Indonesia
}

\begin{abstract}
Purpose - The presence of Grab has invited many discussions. The purpose of this study is to know the role of Grab on changes in social life in Bengkulu city both in terms of Grab drivers, consumers, and other conventional transportation.

Method - This study uses a qualitative approach with an in-depth interview method. The total respondents in this study are 38 people consisting of 5 people from Grab drivers, 30 people from consumers, and five people from conventional transportation.

Result - This study found that there were changes in Grab drivers' income, but there were no social changes in Grab drivers. On the other hand, there were social changes in Grab consumers and conventional drivers.

Implication - This study can be used by public, government, and private sector to understand better consumer behaviour in online transportation field.

Originality - As the growth of online transportation in Indonesia is increasing, this study offers early understanding upon the phenomena.
\end{abstract}

Keywords: online transportation, social change, consumer behaviour, qualitative, Bengkulu, Indonesia 


\section{Introduction}

Technological developments have had an impact on all aspects of life. An all-encompassing internet network and the fast advancement of smartphones are commonplace these days. Almost all places have internet coverage. Most Indonesians have also used smartphones for their daily activities. In addition, smartphones can be used by all levels of society from all walks of life and without age restrictions.

Maharani in Yunus (2013) explains that the rapid development of internet technology causes changes in society. Many new businesses have sprung up involving the internet in business activities. One of them is a business in service provider-based applications in the field of online-based transportation modes. Online-based transportation provides breakthroughs to consumers and offers solutions and answers to various public concerns about public transportation services. One of the online-based transportation that is already present in Bengkulu is Grab. Bengkulu people positively welcome Grab's presence.

However, the development of Grab has also invited many pros and cons in the community. From the time Grab arrived in Indonesia, it has caused a lot of debate in various circles. There is a positive response from consumers who accept Grab as an alternative transportation option. In addition, people who have not found work and groups of workers who use Grab to be drivers are looking for additional income.

However, some people also gave negative responses because the presence of Grab could threaten conventional transportation, namely motorcycle taxis, public transportation, conventional taxis, and pre-existing pedicab drivers. The presence of Grab endangers the sustainability of public transportation that has existed for a long time. This negative response was shown through protests to the Government to prohibit Grab from operating in the area. In addition, the beating of Grab drivers is also rife with conventional taxi drivers and public transportation.

The two different responses raise questions for researchers, namely how far Grab's presence plays a role in people's social life. This study aimed to determine the role of Grab in social change in terms of Grab drivers, Grab consumers, and other conventional 
transportation. Besides that, the condition of Bengkulu City, not only it has a small size and population, is also different objects of research. The population of Bengkulu Province as of semester II of 2019 is $2,007,827$ people (BPS Bengkulu). The population in Bengkulu City is 369,539 people (BPS Bengkulu). The small number of residents is different from the people in other areas so that the researcher feels worthy of being researched.

\section{Literature review}

In a literal context, transportation transfers people or goods from one place to another using a vehicle driven by humans or machines. Transportation is used to make it easier for humans to carry out their daily activities. According to Salim (2000), transportation is moving goods (cargo) and passengers from one place to another. There are two elements in transportation, namely moving/moving and physically changing the place of goods (commodities) and passengers to other sites.

Recently, the transportation transformation in Indonesia has undergone significant changes. Technological developments also have an impact on the world of transportation in Indonesia. This development can be seen from the emergence of online-based transportation models in major cities in Indonesia. Online transportation is a new thing that makes it easier for people in terms of transportation and other things. According to Nikkei, this convenience has resulted in many Grab's online transportation users, which is shown by the number of users of 18 million per month. Online transportation uses online media in managing orders. So it is not surprising that many Indonesian businesspeople collaborate with Grab in running their business, especially in delivering goods.

\section{Grab}

Grab Holdings Inc., formerly known as MyTeksi and GrabTaxi, are companies engaged in providing transportation where. The company was initially established in Malaysia and is now based in Singapore. Grab offers other services, namely food shuttle and digital payment services through applications on smartphones. The development of Grab in Indonesia began in 2014. Grab managed to collect 5 million drivers throughout Indonesia in 2017. 
Grab founders Anthony Tan and Hook Ling Tan aim to create an easy and hassle-free transportation system. Grab's success in Indonesia is none other than the convenience that Grab offers to consumers. In the past, consumers had difficulty finding transportation that could pick them up directly from home. Now that there is Grab, consumers are not challenged to find a ride. This convenience makes consumers switch to using Grab, which is shown by the number of Grab users per month, which is 18 million, according to Nikkei.

\section{Social transformation}

Martono (2012) states that sociology is the study of society in a social system. A community always experiences changes in the social system. Changes that occur can be minor changes to a substantial degree of adaptation to influence human activities or behaviour significantly. Change can also cover both narrow and broad aspects. Limited aspects include aspects of individual behaviour and thought patterns. The expansive element can be in the form of changes in the structure of society, which can affect the development of society in the future. In this study, the changes studied were narrow, namely social change, which included behaviour and individual thought patterns.

Gillin and Gillin in Soekanto (2009) define social change as a change that occurs as a variation of the accepted way of life due to changes in geographical conditions, material culture, population composition, ideology, or diffusion or discoveries in society. New things influence social change in society, creating a different situation from the previous case in the social system. Change occurs because there are differences in the old social conditions and other times between the same social systems. According to Marx and Engels (1848), conflict theory states that individuals and groups try their best to maximize the benefits obtained. Meanwhile, society is in a constant but unbalanced phase. Conflict theory is the theoretical basis in this study because it can explain social changes from Grab due to individuals and groups who want the maximum benefit from technology for the transportation sector.

\section{Characteristics of social change}

Not all changes that occur in society can be called social changes. According to Macionis (1996), there are several characteristics of social change, namely as follows: 
1. Social change occurs in every society, although the level of social change varies

2. Social change often develops in a direction that is difficult to control.

3. Social change often triggers controversy, mainly because it gets a variety of conflicting meanings,

4. Social change can be beneficial for certain parties but can harm other parties at the same time.

How much the rate of change differs from one community group to another. Some changes happen quickly, but some changes are slow in the process. It all depends on the needs, awareness, and actions of the group members. Social change can be recognized, but social change cannot be planned. Changes in the use of online transportation can be predicted due to changes in technology. However, no one could expect online transportation to have such a vast social effect that reaches regions in Indonesia.

Social change is usually controversial. When society is faced with a change in both the social and economic fields, the community's response will initially be surprised, but gradually, they can accept the changes. Although in the beginning, changes will be challenging to obtain.

The use of online transportation can lead to social changes from an economic and social perspective. This change is in accordance with research conducted by the Centre for Strategic and International Studies (CSIS) in 2019, which found that selfemployed workers on the Grab platform had contributed IDR 77.4 trillion to the Indonesian economy. In addition, Grab partners also experience significant changes in their quality of life. The Demographic Institute of the Faculty of Economics and Business, University of Indonesia (LD FEB UI) researched in 2019 and found that Gojek had contributed to the Indonesian economy worth 104.6 trillion.

Judging from these findings, research on the role of Grab on social change, especially in remote areas, namely Bengkulu City, is feasible to do. Following Macionis' explanation regarding the characteristics of social change, namely that it can benefit one party but can harm the other. In this study, three changes will be observed, namely: (1) There is a change in social and economic 
behaviour that is positive in Grab drivers, (2) There is a change in social and economic behaviour that is positive for Grab consumers, (3) There is a change in social behaviour and negative economy in conventional drivers.

\section{Methodology}

This research is qualitative. According to Sugiyono (2009), qualitative research methods are studies used to investigate, find, describe, and explain the quality or privilege of social influences that cannot be defined, measured, or described through a quantitative approach.

Data were collected using the interview method to the respondents. The total respondents in this study were 15 respondents with details: five respondents for Grab drivers, five respondents for Grab consumers, and five respondents for conventional transportation drivers. The questions were structured according to the background of the respondent group, and in-depth interviews were conducted to find out their perception of Grab and its role in social change.

Sampling using purposive sampling is a sampling technique by selecting several criteria (Cooper \& Schindler, 2014). Purposive sampling is used because the respondents must use the Grab application to grab drivers and conventional transportation. Research data is primary data obtained through direct interviews with respondents.

\section{Operationalization definition}

The variables of social change in this study refer to John Luis Gillin and John Phillip Gillin in Soekanto (2009), namely changes that occur as a variation of the accepted way of life due to changes in geographical conditions, material culture, population composition, ideology, and diffusion or discoveries in society. This study's social change measurement instrument is that there are economic changes in Grab drivers, Grab consumers, and conventional drivers and changes in social relations for Grab drivers, Grab consumers, and traditional drivers. There is no definite benchmark, but the determination of the occurrence of social change or not is seen from the results of in-depth interviews with the three respondents above. 
Table 1. Data of respondents and the economic changes

\begin{tabular}{ccccccc}
\hline \multirow{2}{*}{ Age } & \multicolumn{2}{c}{$\begin{array}{c}\text { Daily income } \\
\text { (in Rupiah) }\end{array}$} & \multicolumn{2}{c}{$\begin{array}{c}\text { Weekly income } \\
\text { (in Rupiah) }\end{array}$} & \multicolumn{2}{c}{$\begin{array}{c}\text { Monthly income } \\
\text { (in Rupiah) }\end{array}$} \\
\cline { 2 - 7 } & Before & After & Before & After & Before & After \\
\hline $32-36$ & $20.000-$ & $51.000-$ & $200.000-$ & $351.000-$ & $1.000 .000-$ & $1.501 .000-$ \\
& 50.000 & 100.000 & 300.000 & 450.000 & 1.500 .000 & 2.000 .000 \\
$42-46$ & $20.000-$ & $51.000-$ & $200.000-$ & $351.000-$ & $1.000 .000-$ & $1.001 .000-$ \\
& 50.000 & 100.000 & 300.000 & 450.000 & 1.500 .000 & 1.500 .000 \\
$27-31$ & $20.000-$ & $51.000-$ & $200.000-$ & $451.000-$ & $1.000 .000-$ & $2.501 .000-$ \\
& 50.000 & 100.000 & 300.000 & 550.000 & 1.500 .000 & 3.000 .000 \\
& & & & & & \\
$37-41$ & $50.000-$ & $101.000-$ & 500.000 & 651.000 & $2.000 .000-$ & $2.501 .000-$ \\
& 100.000 & 150.000 & above & above & 2.500 .000 & 3.000 .000 \\
& & & & & & \\
$17-21$ & $20.000-$ & $51.000-$ & $200.000-$ & $151.000-$ & $1.000 .000-$ & $200.000-$ \\
& 50.000 & 100.000 & 300.000 & 250.000 & 1.500 .000 & 500.000 \\
& & & & & & \\
\hline
\end{tabular}

\section{Results and discussion}

The research was conducted in 2019, and the data collected in total amounted to 38 respondents consisting of 5 Grab driver respondents, $30 \mathrm{Grab}$ consumer respondents, and five conventional driver respondents. Respondent table data can be seen in Table 1.

The results show that the income received by Grab drivers per day, week, and month has increased before joining Grab and after joining Grab. It can be concluded that there is an increase in the income of Grab drivers. This increase is in line with previous research

Table 2. Social changes of Grab's drivers

\begin{tabular}{|c|c|c|c|c|c|}
\hline Name & $\begin{array}{l}\text { Grab } \\
\text { community } \\
\text { presence }\end{array}$ & $\begin{array}{l}\text { Joining in } \\
\text { Grab } \\
\text { community }\end{array}$ & $\begin{array}{l}\text { Social } \\
\text { change } \\
\text { presence }\end{array}$ & Social changes & $\begin{array}{l}\text { Duration } \\
\text { of work }\end{array}$ \\
\hline $\begin{array}{c}\text { Avid } \\
\text { Syahputra }\end{array}$ & Yes & No & No & $\begin{array}{l}\text { No, instead more } \\
\text { debt }\end{array}$ & 24 hours \\
\hline Budi & Yes & Yes & Yes & Add relations & 20 hours \\
\hline Koko & Yes & No & No & $\begin{array}{l}\text { There is } \\
\text { additional } \\
\text { income, but there } \\
\text { is competition } \\
\text { among grab } \\
\text { drivers }\end{array}$ & 7 hours \\
\hline Hamka HS & Yes & No & No & $\begin{array}{l}\text { Life gets more } \\
\text { complicated, car } \\
\text { loan increases, } \\
\text { hard to find other } \\
\text { jobs }\end{array}$ & 24 hours \\
\hline $\begin{array}{c}\text { Diky } \\
\text { Satriansyah }\end{array}$ & Yes & No & Yes & $\begin{array}{l}\text { The p roper way } \\
\text { to get along }\end{array}$ & 24 hours \\
\hline
\end{tabular}

Journal of Islamic Economics, Management, and Business-Vol 2. No.2 (2020) 
, so this research supports previous research which stated that there was an increase in the income of Grab drivers.

Table 3 shows the social changes perceived by consumers. The study results show that consumers feel that Grab's presence JIEMB | 62 helps their lives become more manageable. 40\% said Grab was very helpful, $33.3 \%$ said Grab was helpful, and $23.3 \%$ believe Grab is indifferent. The majority of $73.3 \%$ of respondents said Grab helped their lives. In addition, $80 \%$ of respondents are also willing to pay more tips if they feel that Grab's service is very satisfying. Regarding social change, respondents stated that they thought a social change

Table 3. Social changes of Grab's consumers

\begin{tabular}{|c|c|c|c|c|c|}
\hline Age & Occupation & $\begin{array}{c}\text { Grab being } \\
\text { helpful }\end{array}$ & $\begin{array}{c}\text { Grab being } \\
\text { helpful for } \\
\text { consumers' life }\end{array}$ & $\begin{array}{l}\text { Willingness } \\
\text { to pay tips }\end{array}$ & $\begin{array}{c}\text { Grab affect } \\
\text { social } \\
\text { changes }\end{array}$ \\
\hline $32-36$ & Entrepreneur & Yes & Very helpful & Yes & Yes \\
\hline $42-46$ & Entrepreneur & Yes & Indifferent & Yes & Yes \\
\hline $17-21$ & Student & Yes & Indifferent & Yes & Yes \\
\hline $17-21$ & Student & Yes & Helpful & Yes & Yes \\
\hline $17-21$ & Student & Yes & Helpful & No & Yes \\
\hline $17-21$ & Student & Yes & Helpful & Yes & Yes \\
\hline $17-21$ & Student & Yes & Very helpful & Yes & Yes \\
\hline $17-21$ & Student & Yes & Very helpful & No & Yes \\
\hline $17-21$ & Student & Yes & Very helpful & Yes & Yes \\
\hline $17-21$ & Student & Yes & Helpful & Yes & Yes \\
\hline $22-26$ & Student & Yes & Indifferent & Yes & Yes \\
\hline $32-36$ & Civil servant & Yes & Very helpful & Yes & Yes \\
\hline $27-31$ & Employee of SOE & Yes & Very helpful & Yes & Yes \\
\hline $27-31$ & $\begin{array}{l}\text { An employee of } \\
\text { private companies }\end{array}$ & Yes & Very helpful & Yes & Yes \\
\hline $27-31$ & $\begin{array}{l}\text { An employee of } \\
\text { private companies }\end{array}$ & Yes & Indifferent & Yes & Yes \\
\hline $17-21$ & Student & Yes & Very helpful & Yes & Yes \\
\hline $22-26$ & Student & Yes & Very helpful & No & Yes \\
\hline $27-31$ & Entrepreneur & Yes & Helpful & Yes & Yes \\
\hline $17-21$ & Student & Yes & Helpful & Yes & Yes \\
\hline $17-21$ & Student & Yes & Very helpful & Yes & Yes \\
\hline $17-21$ & Student & Yes & Helpful & Yes & Yes \\
\hline $27-31$ & Employee of SOE & Yes & Helpful & Yes & Yes \\
\hline $27-31$ & Civil servant & Yes & Not helpful & Yes & Yes \\
\hline $17-21$ & Student & Yes & Helpful & Yes & Yes \\
\hline $27-31$ & Entrepreneur & Yes & Very helpful & No & Yes \\
\hline $27-31$ & Civil servant & Yes & Indifferent & Yes & Yes \\
\hline $17-21$ & Student & Yes & Indifferent & No & Yes \\
\hline $22-26$ & Employee of SOE & Yes & Helpful & No & Yes \\
\hline $17-21$ & Student & Yes & Indifferent & Yes & Yes \\
\hline $17-21$ & Student & Yes & Very helpful & Yes & Yes \\
\hline
\end{tabular}


Table 4. Income changes of conventional drivers

\begin{tabular}{ccccccc}
\hline & \multicolumn{2}{c}{$\begin{array}{c}\text { Daily income } \\
\text { (in Rupiah) }\end{array}$} & \multicolumn{2}{c}{$\begin{array}{c}\text { Weekly income } \\
\text { (in Rupiah) }\end{array}$} & \multicolumn{2}{c}{$\begin{array}{c}\text { Monthly income } \\
\text { (in Rupiah) }\end{array}$} \\
\cline { 2 - 7 } Age & Before & After & Before & After & Before & After \\
\hline $32-36$ & $101.000-$ & $101.000-$ & $351.000-$ & $300.000-$ & $2000.000-$ & $1.501 .000-$ \\
& 150.000 & 150.000 & 450.000 & 400.000 & 2.500 .000 & 2.000 .000 \\
$42-46$ & $101.000-$ & $201.000-$ & $450.000-$ & 651.000 & $850.000-$ & $1.001 .000-$ \\
& 150.000 & 250.000 & 550.000 & above & 1.000 .000 & 1.500 .000 \\
$37-41$ & 300.000 & 300.000 & 651.000 & 651.000 & 3.001 .000 & 3.001 .000 \\
& above & above & above & above & above & above \\
$27-31$ & $251.000-$ & $251.000-$ & $451.000-$ & $451.000-$ & $2.501 .000-$ & $2.501 .000-$ \\
& 300.000 & 300.000 & 550.000 & 550.001 & 3.000 .000 & 3.000 .000 \\
$42-46$ & 300.000 & 300.000 & $451.000-$ & $451.000-$ & 3.001 .000 & 3.001 .000 \\
& above & above & 550.000 & 550.002 & above & above \\
\hline
\end{tabular}

from the presence of Grab. Respondents noted that the company of Grab helped them buy the things they needed without abandoning their college assignments so that the time efficiency benefits that Grab provides to consumers make positive social changes for Grab consumers.

Table 4 shows the income changes of conventional drivers. There is a negative economic change in conventional drivers. The emergence of Grab could cause an adverse change that impacts the decline in the number of conventional vehicle users.

Table 5 shows the social changes of conventional drivers. The results show positive social changes since the emergence of Grab. Conventional drivers say they are increasingly discussing competition with Grab and ways to fight Grab, such as lowering travel or bus costs for long-distance locations between districts.

Table 5. Social changes of conventional drivers

\begin{tabular}{|c|c|c|c|c|c|c|}
\hline ID & $\begin{array}{l}\text { Community } \\
\text { presence }\end{array}$ & $\begin{array}{l}\text { Join in } \\
\text { communi } \\
\text { ty }\end{array}$ & Social changes & $\begin{array}{c}\text { Feelings } \\
\text { when } \\
\text { working }\end{array}$ & $\begin{array}{l}\text { Duration of } \\
\text { work }\end{array}$ & $\begin{array}{c}\text { Type of } \\
\text { transportation }\end{array}$ \\
\hline 1 & No & No & $\begin{array}{l}\text { No, instead more } \\
\text { debt }\end{array}$ & Happy & $>17$ hours & Taxi \\
\hline 2 & No & No & More debt & Uncomfortable & $>17$ hours & Others \\
\hline 3 & Yes & Yes & $\begin{array}{l}\text { Stronger bond } \\
\text { because of tight } \\
\text { competition }\end{array}$ & Comfortable & $\leq 12$ hours & Travel \\
\hline 4 & No & No & $\begin{array}{l}\text { More friends, more } \\
\text { discussion about } \\
\text { travelling }\end{array}$ & Comfortable & $\leq 16$ hours & Travel \\
\hline 5 & Yes & Yes & $\begin{array}{l}\text { More friends for } \\
\text { discussion }\end{array}$ & Happy & $\leq 16$ hours & Bus \\
\hline
\end{tabular}




\section{Conclusion}

This study found different results from previous studies. Regarding the role of Grab in Grab drivers, there are socioeconomic changes, but there are no changes in social relations.

JIEMB | 64 Competition between drivers also contributes to this, so that social change tends to be negative. This research provides new findings that competition between Grab drivers jeopardizes social relations and does not build solidarity among Grab drivers.

Grab's role in social change for Grab's consumers is supported because consumers consider the emergence of Grab to affect social and economic change positively. Grab makes it easy for consumers both in transportation and other social activities. Therefore, the role of $\mathrm{Grab}$ is positive regarding the social change of Grab consumers.

The role of Grab in conventional drivers' social relations shows positive results regarding social relations. This is demonstrated by the closer relationship between conventional drivers, namely often discussing and supporting each other. However, the role of grabs on income changes shows negative results. Revenue has decreased since the emergence of Grab in Bengkulu City.

In future research, the researcher recommends examining the role of grabs on unemployment rates and cultural change. The object of study can also be done on online transportation Grab and Gojek, Maxim, and others.

\section{References}

Cooper, D.R., and Schindler, P.S. 2014, "Business Research Methods, 12th ed. Amerika": Mc. Graw Hill

Darwin, Charles. (1859). On The Origin of Species b Means of Natural Selection, or The Preservation of Favoured Races in The Struggle for Life. United Kingdom of Great Britain and Ireland: D. Appleton and Company

Djazifah ER, Nur. (2012). Modul Pembelajaran Sosiologi: Proses Perubahan Sosial Di Masyarakat. UNY: LPPM

Horton, P.B dan Hunt, C.L. (1992). Sosiologi. Jakarta: Erlangga

Macionis, John J. (1997). Sociology. 6th Ed. Prentice Hall: New York

Marx, K and Engels, F. (1848). The Communist Manifesto. United Kingdom 
Martono, Nanang. (2012). Sosiologi Perubahan Sosial; Perspektif Klasik, Modern, Posmodern dan Poskolonial. Edisi Revisi. Jakarta : Raja Grafindo Persada

Ogburn, William F. (1964). On Culture and Social Change.1st Ed. University of Chicago Press

Salim, Abbas. (2000). Manajemen Transportasi. Cetakan Pertama. Edisi Kedua. Jakarta : Raja Grafindo Persada

Soekanto, Soerjono. (2009). Sosiologi Suatu Pengantar. Jakarta: Rajawali Press

Sugiyono. (2009). Metode Penelitian Kuantitatif, Kualitatif dan R\&D, Bandung : Alfabeta

Salim, Agus. (2002). Perubahan Sosial. Yogyakarta: PT Tiara Wicana

Taupan, Muhammad. (2013). Sosiologi Untuk Sekolah Menengah Atas/ Madrasah Aliyah Kelas XII. Bandung: CV Yrama Widya.

Yunus, Mahmud. (2017), "Go-Jek Sebagai Simbol Perubahan Sosial dan Ekonomi Di Kota Tegal," Jurnal IImiah Pendidikan Ekonomi, Vol.2, No.2, pp. 59-68 
Afrima Widanti, Syamsul Bahri, \& Dewi Rahmayanti

JIEMB | 66

Journal of Islamic Economics, Management, and Business-Vol 2. No.2 (2020) 